\title{
Evaluation of the quality of services of the
} university Restaurant of the Federal University of Bahia in the users perception

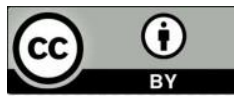

\author{
Avaliação da qualidade dos serviços do restaurante universitário \\ da Universidade Federal da Bahia na percepção dos usuário
}

Bárbara Andreize Dias Rosa dos Santos (barbara_andreize@hotmail.com ) Universidade Federal da Bahia, Brasil Luciana Alves Rodas Vera (lu.alvesvera@gmail.com ) Universidade Federal da Bahia, Brasil

\section{ABSTRACT}

This work consists of a research carried out at the University Restaurant (UR) of the Federal University of Bahia, located at the Ondina campus, in the city of Salvador, which aims to evaluate the quality levels of the services provided, in the consumer's perception. For this, a descriptive research with quantitative approach was conducted with survey applied to costumers. As an instrument for assessing service quality, an adaptation of the SERVPERF scale by Cronin and Taylor (1992) was used. After the results, it is possible to verify that the UFBA UR presents a good level of service quality, having been better evaluated in the dimensions of readiness, tangibility and safety, in that order. However, problems have been identified with waiting time in line and UR concern about what customers like to eat. These two aspects are not well evaluated by consumers and are part of the Empathy dimension items. In addition, the Reliability dimension was also not well evaluated by respondents, which means that the UR has difficulty providing the promised service accurately. These results suggest to the restaurant's management a direction of resources directed to the qualification of its employees and marketing research.

Keywords: Service Quality; University restaurant; SERVPERF.

\section{RESUMO}

Este trabalho consiste em uma pesquisa realizada no Restaurante Universitário (RU) da Universidade Federal da Bahia, localizado no campus de Ondina, na cidade de Salvador, que objetiva avaliar a percepção dos usuários acerca da qualidade dos serviços prestados. Para tanto, foi realizada uma pesquisa descritiva com abordagem quantitativa e aplicação de questionário aos clientes. Como instrumento de avaliação da qualidade nos serviços utilizou-se uma adaptação da escala SERVPERF, de Cronin e 
Taylor (1992). Após os resultados, pôde-se verificar que o RU da UFBA apresenta um bom nível de qualidade dos serviços tendo sido mais bem avaliado nas dimensões da qualidade Presteza, Tangibilidade e Segurança, nessa ordem. Entretanto, foram identificados problemas com o tempo de espera na fila e com a preocupação do RU com o que os clientes gostam de comer. Estes dois aspectos não foram bem avaliados pelos consumidores e fazem parte dos itens da dimensão Empatia. Além disso, a dimensão Confiabilidade também não foi bem avaliada pelos respondentes, o que significa que o RU tem dificuldade em oferecer o serviço prometido com exatidão. Esses resultados sugerem à gestão do restaurante um direcionamento de recursos voltados para a capacitação de seus funcionários e pesquisas de Marketing.

Palavras-chave: Qualidade em serviços, Restaurante Universitário, SERVPERF.

\section{INTRODUCTION}

Public services are created by the Public Administration to meet the collective needs of citizens. In recent years, according to Trevisan, Lobler, Visentini and Bobsin (2009), public management in Brazil has been undergoing structural reforms in order to professionalize, modernize, democratize and make its processes transparent, thus improving its services with the aim of better serving to society's demands.

Given this context of transformations that public management has been going through, there is a notable increase in studies related to consumer satisfaction and quality of provided services, previously restricted to the private sector, which assumes great importance in the redesign of the State's role. These changes, according to Coutinho (2000), can be attributed to the managerial public administration model that, inspired by the private sector, abandons characteristics of bureaucratic administration, focused on the State apparatus, and prioritizes the quality improvement of the services provided to the citizens.

According to Santos (2016), among the services offered to the population are the services provided by public universities that, in addition to offering professional training, are able to serve the academic community with 
the provision of fundamentally important student assistance services, such as housing, health and food.

According to Silva (2017), student assistance policies are very important throughout the academic life of students, especially those who have a low purchasing power or who live far from where they study. For him, these policies have a direct impact on the quality of the student's academic performance and contribute to ensuring the permanence of students at the university.

In the context of student assistance services are university restaurants, which, according to Santos (2016), are units that provide nutritionally adequate food services to the academic community and serve as a mechanism for the integration and promotion of student assistance. What is worrying, however, is that the university restaurants in Brazil, due to recent cuts in funds and a increase in demand, face a management challenge related to quality in the provision of services and consumer satisfaction.

According to Sguissardi (2006):

Public resources destined to Federal Higher Education Institutions (IFES) in 1994 represented $0.91 \%$ of Brazilian GDP; in 2002 this percentage reached $0.64 \%$, a reduction of $30 \%$. Meanwhile, in the same period, enrollment in these institutions increased by $37 \%$ (Sguissardi, 2006, p. 213).

The fact that resources are scarce and the growing demand greatly limits the investments, such as improvements in the product, services and the place's structure, which would be fundamental for better provision of services. With this, serious management problems arise, along with the difficulties of managers in deciding how to best allocate resources. Therefore, seeking to establish a policy of continuous improvement in the services provided by the UR, the service quality survey will be a tool of fundamental importance. 
This research provides insights regarding the management of the UFBA UR, in concern to aspects of the quality of services provided to the consumer, in order to have a better use of public resources. In addition, it is possible to identify the critical points that need more attention and management by the institution. According to Teboul (1999), the best way to measure the quality of a service is to know the client's perception of the performance or value of the service offered to him. Thus, this work starts from the following research question: What is the evaluation of the quality of services of the UFBA university restaurant located on the Ondina campus in the perception of users?

In order to answer this question, this research has the general objective of evaluating the quality of services provided by UFBA's university restaurant in the perception of customers. To achieve the general objective, the following specific objectives are established: to know the profile of consumers in the UR of UFBA; to measure the quality of the restaurant's services; and to identify the levels of reliability, responsiveness, assurance, empathy and tangibles provided by the restaurant from the users' perspective.

\section{THEORETICAL REFERENCE}

\section{Service Quality}

According to Pena et al. (2012), evaluating the quality of a service is not an easy task, since, unlike tangible products, services have intangible aspects, are heterogeneous, are subject to different interpretations and judgments. The first research on service quality emerged from comparisons between what the user expected from the service and what they perceived. With that, the authors stated that "promoting a quality service means effectively reaching the needs and expectations of a user" (Pena et al., 2012, p. 2). 
Lovelock (2011) states that a service is considered quality when it consistently exceeds customer expectations. For the author, delivering quality services with cost efficiency is a challenge for organizations.

The main study in the field of service quality was developed in 1985, by Parasuraman, Zeithaml and Berry. According to Lovelock (2011), the authors define service quality as the difference between consumer expectations and perception of service performance, and identified 5 factors to assess it. The five dimensions proposed by the authors are: reliability, responsiveness, assurance, empathy and tangibles, described in Table 1:

Table 1- Service quality assessment factors

\begin{tabular}{|c|c|}
\hline DIMENSÃO & CARACTERÍSTICAS \\
\hline Reliability & Offering the promised service accurately. \\
\hline Responsiveness & $\begin{array}{c}\text { Willingness to help customers and provide immediate } \\
\text { service. }\end{array}$ \\
\hline Assurance & $\begin{array}{c}\text { Knowledge and courtesy of employees and their ability to } \\
\text { convey confidence and security. }\end{array}$ \\
\hline Empathy & \begin{tabular}{c} 
Individualized attention to customers, closeness and \\
communication. \\
\hline Tangibles
\end{tabular} \\
and communication materials \\
\hline
\end{tabular}

Source: Prepared by the authors (2019), adapted from Parasuraman, Zeithaml and Berry (1985).

As stated by Parasuraman, Zeithaml and Berry (1988), the service quality can be measured by the difference between consumer expectation and the perception of the real performance. Consumer expectations are strongly influenced by four factors: (1) word of mouth, which concerns what the consumer hears about the service; (2) personal needs, individual characteristics and circumstances; (3) past experiences that the consumer 
has had with the service; and (4) external communication, which corresponds to any and all messages, direct or indirect, transmitted by the organization.

According to Souza (2012), in restaurant services, customers consider three dimensions to measure the quality of a service: functional, mechanical and human. The functional dimension is related to factors such as food quality, variety of the menu, drinks and ingredients, among others; in the mechanical dimension there are environmental aspects such as layout, decoration, lighting and physical installations; and the human dimension is associated with the performance, behavior and appearance of employees and which, according to the author, is the one that most influences the customers perception.

According to Parasuraman, Zeithaml and Berry (1985), the perceived quality can be understood as the difference between the customer's expectations and the perception of the real performance of a given service. However, Cronin and Taylor (1992) consider that performance minus expectation does not have a direct relation with Perceived Quality, since the evaluation of Performance alone offers more adequate results in measuring the construct.

According to Gianesi and Corrêa (1994), customer's perception of service quality is formed by two main factors: service provision and communication. For them, customer perception can be modified according to the transmitted communication, and service provision is the main responsible for it.

Teboul (1999) states that there are four factors that will contribute to the perception of service quality: advertising, interaction with employees, experience with the service and word of mouth. The authors also emphasize that an image formed by the customer is difficult to change.

As stated by Marcheti and Prado (2001), several methods can be applied to measure Customer Satisfaction and Perceived Quality, however, 
the most used ones are based on the Nonconformity Paradigm, in which Satisfaction and Quality can be measured through the difference between Expectation and Performance. In the next topic, two theoretical models widely used in the academic environment to evaluate the perceived quality of services will be presented.

\section{SERVQUAL and SERVPERF tools}

After a survey conducted in 1985 with customers to identify the dimensions of service quality (Table 1), Parasuraman, Zeithaml and Berry developed a model of gap analysis, based on the Nonconformity Paradigm. In this model, the SERVQUAL tool is used to assess the quality of a service based on customer expectations.

According to Santos (2016), in the model proposed by the authors cited above, there are five gaps between service provision and the quality expected by the customer that result in the customers' dissatisfaction with the service. Gap 1 corresponds to the difference between what service providers believe customers think and the real expectations and needs of customers. Gap 2 corresponds to the difference between the managerial understanding of customer expectations and the quality standards determined by the company. Gap 3 corresponds to the difference between the quality standards determined by the company and what is offered, that is, its real performance. Gap 4 corresponds to the discrepancy between what the company promises through communication channels and what is actually delivered. Gap 5 corresponds to the gap between customer expectations and their perceptions of the delivered service. 
Figure 1-Gap model of service quality

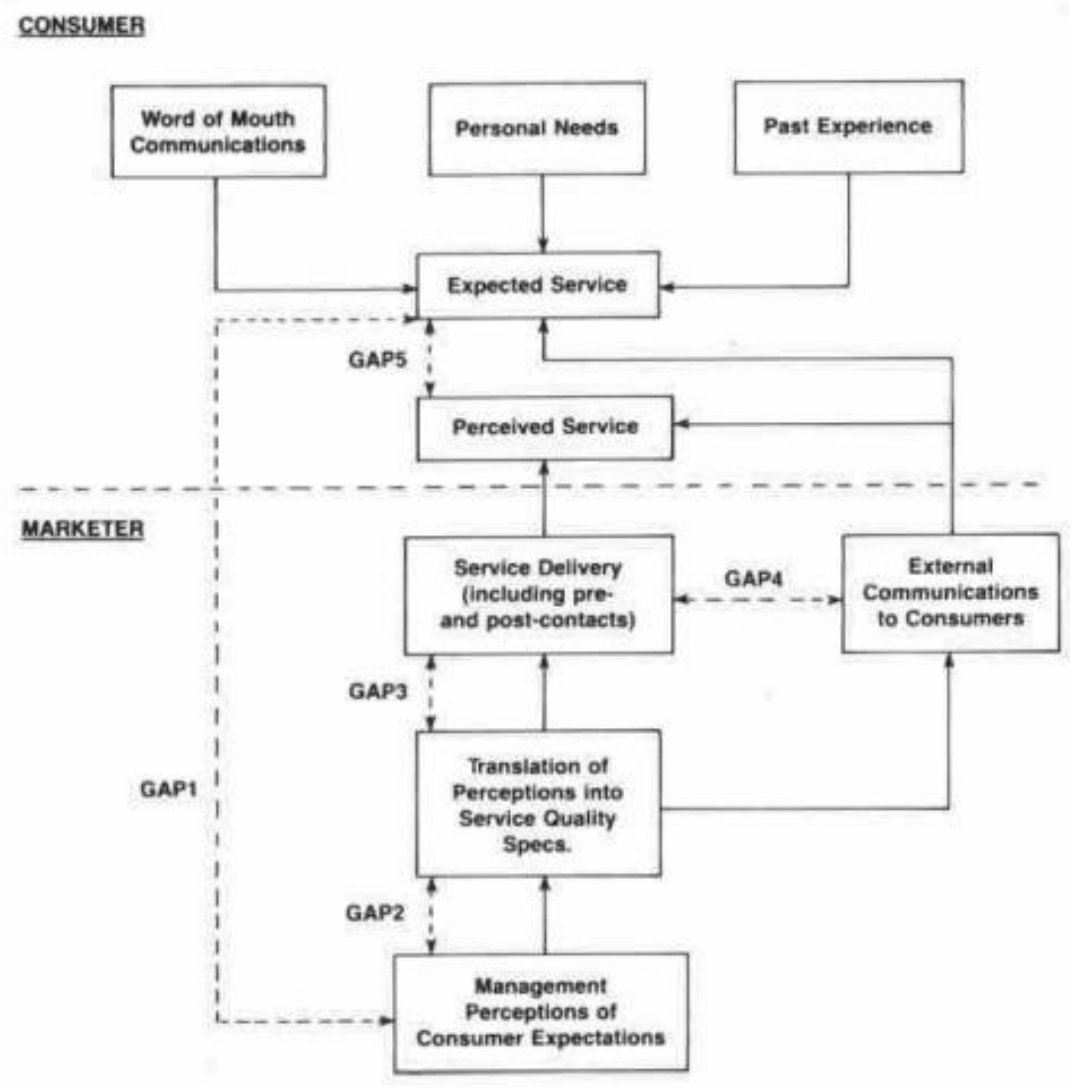

Source: Parasuraman et al. (1985)

Still based on Santos (2016), the Gaps model (Figure 1) resulted in the SERVQUAL scale, divided into three parts. The first part assesses customer expectations (22 items), the second assesses customer perceptions ( 22 items) and the third is the global evaluation of the company's performance through the five dimensions of quality, proposed in 1985 by the authors Parasuraman, Zeithaml and Berry.

Table 2 - Application of the SERVQUAL Scale

\begin{tabular}{|c|l|l|l|}
\hline Item & Dimension & Expectation & Performance \\
\hline \multirow{2}{*}{1} & & $\begin{array}{l}\text { They should have modern } \\
\text { equipment. }\end{array}$ & $\begin{array}{l}\text { XYZ have modern } \\
\text { equipment. }\end{array}$ \\
\cline { 3 - 4 } & & $\begin{array}{l}\text { Their physical facilities should be } \\
\text { visually attractive. }\end{array}$ & $\begin{array}{l}\text { XYZ's physical } \\
\text { installations are visually }\end{array}$ \\
\hline
\end{tabular}




\begin{tabular}{|c|c|c|c|}
\hline & & & attractive. \\
\hline 3 & & $\begin{array}{l}\text { Their employees should be well } \\
\text { dressed and neat. }\end{array}$ & $\begin{array}{l}\text { XYZ's employees are } \\
\text { well dressed and neat.. }\end{array}$ \\
\hline 4 & Tangibles & $\begin{array}{l}\text { The appearance of the } \\
\text { companies facilities should be } \\
\text { maintained according to the } \\
\text { offered service. }\end{array}$ & $\begin{array}{l}\text { The appearance of } \\
\text { XYZ's physical facilities is } \\
\text { maintained according } \\
\text { to the offered service. }\end{array}$ \\
\hline 5 & \multirow{5}{*}{ Reliability } & $\begin{array}{l}\text { When companies promise to do } \\
\text { something at a certain time, they } \\
\text { should do it. }\end{array}$ & $\begin{array}{l}\text { When XYZ promises to } \\
\text { do something at a } \\
\text { certain time, they really } \\
\text { do. }\end{array}$ \\
\hline 6 & & $\begin{array}{l}\text { When customers have a problem } \\
\text { with companies, they should be } \\
\text { supportive and reassuring. }\end{array}$ & $\begin{array}{l}\text { When you have a } \\
\text { problem with } X Y Z \text {, they } \\
\text { are supportive and } \\
\text { reassuring. }\end{array}$ \\
\hline 7 & & Companies should be trustworthy. & $\mathrm{XYZ}$ is trustworthy. \\
\hline 8 & & $\begin{array}{l}\text { They should provide the service at } \\
\text { the promised time. }\end{array}$ & $\begin{array}{l}\mathrm{XYZ} \text { provides the service } \\
\text { at the promised time. }\end{array}$ \\
\hline 9 & & $\begin{array}{l}\text { They should maintain their records } \\
\text { correctly. }\end{array}$ & $\begin{array}{l}\text { XYZ maintains its records } \\
\text { correctly. }\end{array}$ \\
\hline 10 & \multirow{4}{*}{ Responsiveness } & $\begin{array}{l}\text { They would not be expected to } \\
\text { inform customers exactly when the } \\
\text { services are performed. }\end{array}$ & $\begin{array}{l}\text { XYZ does not say } \\
\text { exactly when the } \\
\text { services will be } \\
\text { performed. }\end{array}$ \\
\hline 11 & & $\begin{array}{l}\text { It is unreasonable to expect } \\
\text { immediate availability of } \\
\text { company employees. }\end{array}$ & $\begin{array}{l}\text { You do not receive } \\
\text { immediate service from } \\
\text { XYZ employees. }\end{array}$ \\
\hline 12 & & $\begin{array}{l}\text { Company employees do not } \\
\text { always have to be available to } \\
\text { help customers. }\end{array}$ & $\begin{array}{l}\text { XYZ employees are not } \\
\text { always willing to help } \\
\text { customers. }\end{array}$ \\
\hline 13 & & $\begin{array}{l}\text { It is normal for employees to be } \\
\text { very busy responding promptly to } \\
\text { requests. }\end{array}$ & $\begin{array}{l}\mathrm{XYZ} \text { employees are } \\
\text { always busy responding } \\
\text { to customer requests. }\end{array}$ \\
\hline 14 & & Customers should be able to trust & You can trust \\
\hline
\end{tabular}




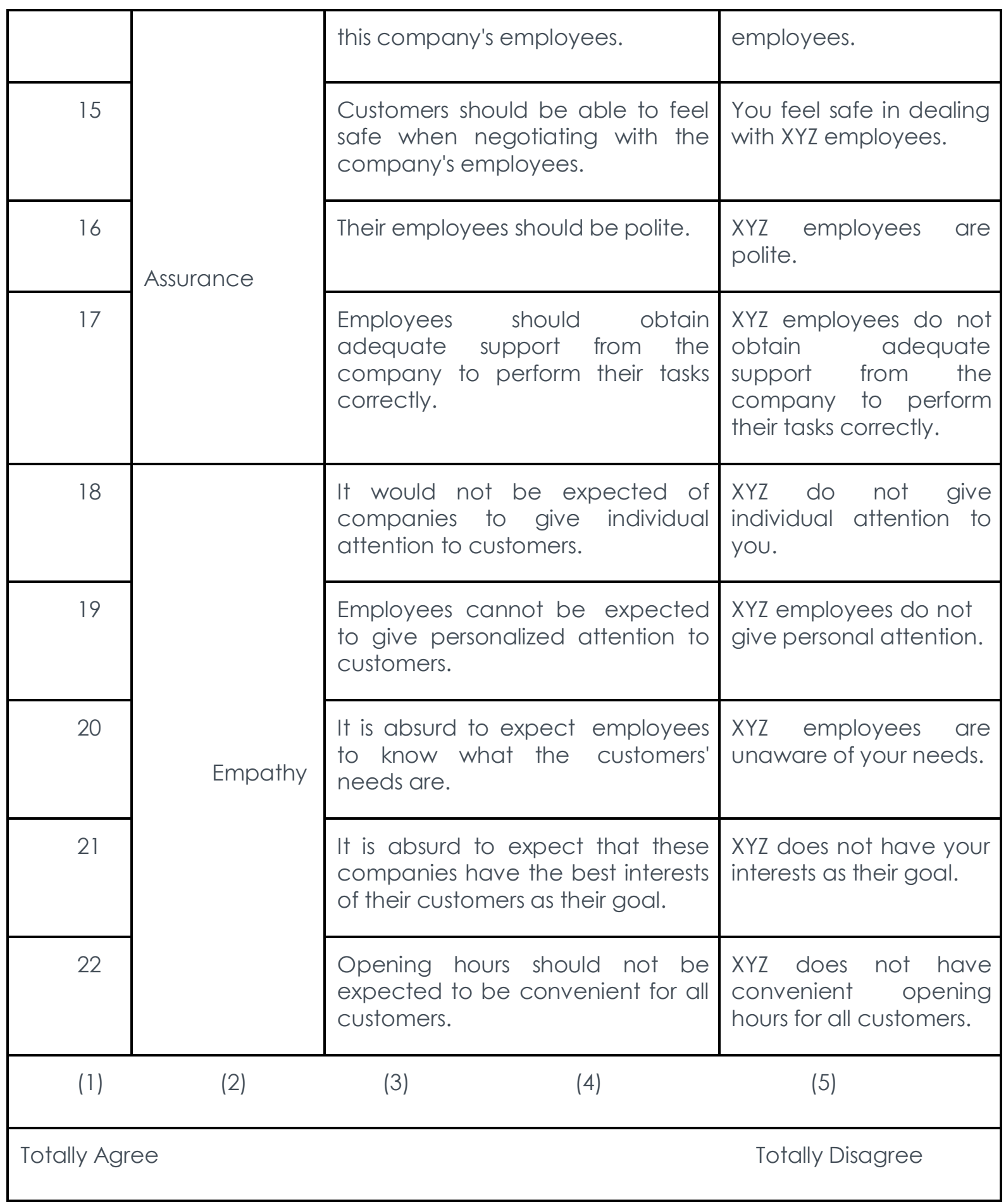

Source: Parasuraman et al. (1988).

The SERVQUAL scale is an instrument for assessing service quality that verifies customers' expectations and perceptions, and which, according to Fernandes (2016), can be applied in several sectors. 
However, Cronin and Taylor (1992), in a study carried out on the conceptualization of Marketing and Service Quality, stated that the nonconformity paradigm, which is based on the SERVQUAL scale, is flawed. The authors then developed a tool called SERVPERF that assesses the quality of a service taking into account only the measurement of the customer's perception. For the authors, the SERVPERF tool is more reliable and presents a smaller survey, in which the data are compared through statistical analysis.

According to Silva, Medeiros and Costa (2009), the SERVPERF scale is more efficient than the SERVQUAL scale because it halves the number of items, which ends up providing greater credibility in the answers.

Table 3 - SERVPERF tool

\begin{tabular}{|c|c|c|}
\hline Item & Dimension & Performance \\
\hline 1 & \multirow{4}{*}{ Tangibles } & XYZ have modern equipments. \\
\hline 2 & & XYZ's physical installations are visually attractive. \\
\hline 3 & & XYZ's employees are well dressed and neat. \\
\hline 4 & & $\begin{array}{l}\text { The appearance of XYZ's physical facilities is maintained } \\
\text { according to the offered service. }\end{array}$ \\
\hline 5 & \multirow{5}{*}{ Reliability } & $\begin{array}{l}\text { When XYZ promises to do something at a certain time, } \\
\text { they really do. }\end{array}$ \\
\hline 6 & & $\begin{array}{l}\text { When you have a problem with } X Y Z \text {, they are supportive } \\
\text { and reassuring. }\end{array}$ \\
\hline 7 & & $\mathrm{XYZ}$ is trustworthy. \\
\hline 8 & & XYZ provides the service at the promised time. \\
\hline 9 & & XYZ maintains its records correctly. \\
\hline 10 & & $\begin{array}{l}\text { XYZ does not say exactly when the services will be } \\
\text { performed. }\end{array}$ \\
\hline
\end{tabular}




\begin{tabular}{|c|c|c|}
\hline 11 & Responsiveness & $\begin{array}{l}\text { You do not receive immediate service from XYZ } \\
\text { employees. }\end{array}$ \\
\hline 12 & & XYZ employees are not always willing to help customers. \\
\hline 13 & & $\begin{array}{l}\text { XYZ employees are always busy responding to customer } \\
\text { requests. }\end{array}$ \\
\hline 14 & \multirow{4}{*}{ Assurance } & You can trust XYZ employees. \\
\hline 15 & & You feel safe in dealing with XYZ employees. \\
\hline 16 & & XYZ employees are polite. \\
\hline 17 & & $\begin{array}{l}\text { XYZ employees do not obtain adequate support from the } \\
\text { company to perform their tasks correctly. }\end{array}$ \\
\hline 18 & \multirow{5}{*}{ Empathy } & XYZ do not give individual attention to you. \\
\hline 19 & & XYZ employees do not give personal attention. \\
\hline 20 & & XYZ employees are unaware of your needs. \\
\hline 21 & & XYZ does not have your interests as their goal. \\
\hline 22 & & $\begin{array}{l}\text { XYZ does not have convenient opening hours for all } \\
\text { customers }\end{array}$ \\
\hline
\end{tabular}

Source: Cronin e Taylor (1992)

\section{University Restaurants}

According to Vidrik (2006), today, with Brazil's economic and social development, the population has spent most of their time away from home, due to the need to engage in activities like school and work. Therefore, we have less time to other activities, such as leisure and preparing our food.

Another aspect noted by the author is the distance between companies and schools in relation to the homes of employees and students, which 
creates the need to have meal units that provide for those who spend most of their time away from home.

In 1950, according to Vidrik (2006), the ministry of education and culture realized that students needed a nutritional meal, which guaranteed the physiological and psychological conditions to maintain their studies. With this, the first University Restaurant was opened at the University of Brazil, in Rio de Janeiro, with the objective of meeting the students' daily nutritional needs.

According to Silva (2017), University Restaurants (URs) of public universities are Food and Nutrition Units (UANs) that offer different meals from those offered in commercial restaurants in the gastronomic sector. They belong to the collective food sector, and aim to lead the production of nutritionally balanced meals of a high hygienic-sanitary standard, so that food can be consumed outside the home. According to him, the scope of this service depends on the Student Assistance program.

According to Santos (2016), University Restaurants are managed by Federal Institutions of Higher Education, to which they are linked, and the provision of their services is limited to the academic community. They can have their activities delegated to third-party companies.

Another important fact about the operation of university restaurants, reported by Santos (2016), is that the resources allocated to the maintenance of activities are linked to the university's budget, which ends up limiting improvement efforts that are fundamental for a better service provision.

In addition to limited resources, University Restaurants face an increasing demand for their services. According to Oliveira (2013), in 2007, with the creation of the Federal Universities Restructuring and Expansion Plan (REUNI), instituted by the Federal Government, there was a significant increase in the number of students and civil servants at Universities.

These questions represent only some of the difficulties encountered in the management of university restaurants. To alleviate them, some universities choose to outsource the service, through a bidding 
process. The problem with this decision is the price charged for the meal, which sometimes becomes expensive, displeasing customers. And in the difficulty of achieving excellence and consistency in services in the presence of intermediaries, who represent the institution, interact with customers and, at the same time, are not under the direct command of the public agency (Santos, 2016, p. 43)

Santos (2016) states that, although University Restaurants face some management difficulties, they are still an excellent option for academics to have low priced, nutritionally balanced and varied meals. In addition, "the URs represent an important mechanism of social inclusion, as they facilitate the permanence of students with economic difficulties at the university until the conclusion of their graduation" (Oliveira, 2013, p.17).

The Federal University of Bahia has three university restaurants to serve its academic community: one is in the Vitória residence, located in the Vitória Corridor; one at the São Lázaro Campus, located in the Federation; and another at the Ondina Campus, located on Avenida Adhemar de Barros, which receives the majority of the public using the university's restaurant and will be the object of this study.

The UR of the Federal University of Bahia, located on the Ondina Campus , offers meals such as breakfast, lunch and dinner at affordable prices to students, teachers and administrative technicians. To use the UR, the student needs to present his / her Registration Certificate at the UR cashier, before making the payment, to enjoy the popular price of $R \$ 2.50$ or to have total gratuity, if he / she is a scholarship student. The UR is available from Monday to Sunday.

According to Caldas (2019), the menu is prepared by the food security nucleus of the Pro-rectory of Affirmative Actions and Student Assistance (PROAE), which oversees the contract between the university and the outsourced company. 


\section{METHODOLOGY}

The present work is a descriptive research that follows a quantitative approach, using a survey method (survey application). Malhotra (2011) states that quantitative research aims to quantify the data in order to allow statistical treatment.

As a data collection instrument, the present research chose uses a survey formed by two blocks of questions. The first block seeks to know the profile of UFBA's regulars. In this block, questions are asked about age, income, bond that the frequenter has with UFBA and frequency with which the interviewee goes to the restaurant during the week. The second block aims at measuring the quality of the services provided by the UFBA restaurant in the perception of its users. In this block, service quality factors were measured, such as Tangibiles, Reliability, Responsiveness, Assurance and Empathy.

For the variables in the second block of the survey, the Likert-type scale was used. For the age and income variables, the Ratio scale was used and, for the frequency and bond variables, the Nominal scale was used. For each attribute present in the second block of the survey, the level of quality was assessed on a scale ranging from 1 to 5 , in which 1 corresponds to "strongly disagree" and 5 to "strongly agree".

According to Slongo and Rossi (1998), the five-point scale offers a break point (3), which is the state of indefinition between agreement and disagreement: there are two points at the ends, one indicating total agreement (5), and the other total disagreement (1); and two points, which are each between the break point and the end, indicating agreement (4) or disagreement (2). The five points offer possibilities for the respondent to express their levels of agreement or disagreement.

The survey for this research was applied in person, from November 1 to 10, to people who were waiting in line for admission to the UFBA University 
Restaurant, which is located on the Ondina campus. Data collection was done at lunchtime, from 11:00 to 14:00.

Marconi and Lakatos (2003) define that population is the set of elements that can be verified under similar conditions. According to the authors, a population can be finite or infinite. The population of the present research comprised all the people who attend the UFBA University Restaurant located on the Ondina campus, from 11 am to 2 pm. The survey was answered by 110 people, frequenter of the restaurant under study, who are scholarship holders (do not pay for the meal) or not (people who pay R \$ 2.50 per meal).

For this work, the non-probabilistic technique of convenience sampling was used, a technique in which "the interviewer's personal judgment is trusted" (Malhotra, 2011), as there was no criterion for the selection of respondents. People who were waiting in line to enter the restaurant had access to the survey. 
Table 4 - Analysis Matrix

\begin{tabular}{|c|c|c|c|}
\hline MAIN GOAL & THEORETICAL & VARIABLES & ITEMS \\
\hline \multirow{9}{*}{$\begin{array}{l}\text { Check the quality of } \\
\text { the services } \\
\text { provided by the } \\
\text { UFBA University } \\
\text { Restaurant }\end{array}$} & \multirow{4}{*}{$\begin{array}{l}\text { Socioeconomic } \\
\text { Profile }\end{array}$} & Age & Q1 \\
\hline & & Income & Q2 \\
\hline & & Frequency & Q3 \\
\hline & & Bond & Q4 \\
\hline & \multirow{5}{*}{ Services / Products } & Tangibles & \multirow{5}{*}{ Q5 } \\
\hline & & Reliability & \\
\hline & & Responsiveness & \\
\hline & & Assurance & \\
\hline & & Empathy & \\
\hline
\end{tabular}

Source: prepared by the authors, 2019.

In the Analysis Matrix, are briefly shown the general objective of the present research, the theoretical dimensions and the question items corresponding to each variable. For data analysis and interpretation, a basic descriptive statistical analysis is performed and the data are tabulated using the EXCEL software.

\section{DATA ANALYSIS}

\section{Analysis of the profile of UR visitors}

Regarding the age group of people who use the services provided by the UFBA's UR, located on the Ondina campus, $85 \%$ of the people who answered the survey belong to the age group of 17 to 30 years old, with an 
average age of 23.7 years, thus being a young audience. The group composed of people with ages between 31 and 40 years old is equivalent to $12 \%$ of respondents and, finally, only $3 \%$ is over 40 years old. The youngest respondent is 17 years old and the most frequent age among respondents was 19 years old.

The income variable aims to trace the economic profile of the regulars, that is, to know how much the interviewees' family income is, approximately. It is possible to verify that the monthly family income of $57 \%$ of the people who answered the survey is between 1 and 3 minimum wages, that is, they have a monthly income of $R \$ 998.00$ to $R \$ 2,994.00$. The group with a family income of 4 to 6 minimum wages corresponds to $34 \%$ of the sample, that is, they earn between $R \$ 3,992.00$ and $R \$ 5,988.00$. Those who earn between $R \$ 6,986.00$ and $R \$ 9,980.00,7$ to 10 minimum wages, represent $6 \%$, and only $3 \%$ of the sample have a family income above $\mathrm{R} \$ 10,978.00,11$ minimum wages. The respondents' average income is $R \$ 1,545.00$.

With the variable frequency of use of the university restaurant, we seek to verify the frequency with which users use the UR's services. The goal is to find out if the majority of users go to the UR regularly. According to Zeithaml et al. (2014), the greater the frequency of contact that a user has with a given service, the more conditions they will have to assess its quality. Among respondents to this survey, $26 \%$ attend the UR daily and $31 \%$ go to the UR 3 to 4 times a week, which means that $57 \%$ (the sum of the two results) are fully able to answer the questions. However, adding the other results $(43 \%)$, it is clear that there is a variability in the frequency of use.

Regarding the "Link with UFBA" item, with representation of 99\%, the users of the restaurant who are linked to the institution in the "Student "category are the vast majority of frequenters among the respondents. Although UFBA has several technical servers, teachers and contractors, these are represented by only $1 \%$ of the sample. 


\section{Analysis of quality perception}

\section{General Analysis of the Dimensions of Quality}

Table 5 shows the averages of the perceptions of the quality of services offered by UFBA UR from the users' perspective. It exposes the 22 items of the SERVPERF scale developed based on the five dimensions of quality proposed by Parasuraman, Zeithaml and Berry in 1985, with the necessary adaptations to the UFBA UR context. They are scored from 1 to 5 , where 1 corresponds to Totally Disagree and 5 to Totally Agree, with 3 as the point of uncertainty.

Table 5 - Perceptions average

\begin{tabular}{|l|r|}
\hline \multirow{2}{*}{ Tangibles } & $\begin{array}{l}\text { Average } \\
\text { s }\end{array}$ \\
\cline { 2 - 2 } & 3,37 \\
\hline 1. The equipment used by the UR is maintained and modern. & 3,16 \\
\hline $\begin{array}{l}\text { 2. The UR facilities (tables, decoration, facade) and the setting } \\
\text { (cleanliness of the environment, air conditioning) are visually attractive and } \\
\text { pleasant. }\end{array}$ & 2,94 \\
\hline 3. UR employees are clean and professional looking. & 3,79 \\
\hline $\begin{array}{l}\text { 4. The appearance of the UR materials associated with the service } \\
\text { (plates, cutlery, buffet food) are arranged in an easy and hygienic way. }\end{array}$ & 3,60 \\
\hline Reliability & 2,59 \\
\hline $\begin{array}{l}\text { 5. When the UR promises customers something, it delivers in a } \\
\text { satisfactory time. }\end{array}$ & 2,76 \\
\hline $\begin{array}{l}\text { 6. The UR provides sufficient and pleasant food service throughout the } \\
\text { opening hours. }\end{array}$ & 2,50 \\
\hline \begin{tabular}{l} 
7. The food provided by the UR is reliable. \\
\hline
\end{tabular} & \\
\hline
\end{tabular}




\begin{tabular}{|c|c|}
\hline 8. The UR does not make any type of error in its services. & 2,03 \\
\hline $\begin{array}{l}\text { 9. When errors occur, the UR records them and its employees show } \\
\text { interest on resolving them. }\end{array}$ & 2,87 \\
\hline Responsiveness & 3,59 \\
\hline $\begin{array}{l}\text { 10. The UR keeps customers informed about the menu offered on each } \\
\text { day. }\end{array}$ & 4,10 \\
\hline 11. UR employees are quick on getting the job done. & 3,64 \\
\hline 12. UR employees are always willing to help customers. & 3,21 \\
\hline 13. UR employees always respond to customer requests. & 3,43 \\
\hline Assurance & 3,12 \\
\hline 14. UR employees inspire confidence from their customers. & 3,13 \\
\hline 15. UR offers security to its customers. & 3,15 \\
\hline 16. UR employees are polite. & 3,23 \\
\hline 17. UR employees are knowledgeable about their products. & 2,99 \\
\hline Empathy & 2,89 \\
\hline 18. UR employees are attentive. & 3,25 \\
\hline 19. UR employees know your needs. & 2,99 \\
\hline 20. The UR has convenient opening hours. & 3,60 \\
\hline 21. The UR is concerned about what customers like to eat. & 2,59 \\
\hline 22. The UR is concerned about queve agility. & 2,02 \\
\hline
\end{tabular}

Source: prepared by the authors, 2019.

As shown in Table 5, among the quality dimensions, the ones that had the highest averages were "Responsiveness" with 3.59 and "Tangibles" with 3.37. "Reliability" dimension had the lowest average, with 2.59. 
Among the attributes, the one with the lowest average was statement 22 - "the UR is concerned with queve agility" - from the dimension "Empathy", with an average of 2.02. The attribute with the highest average was statement 10 - "The UR keeps the customer informed about the menu offered on each day" - from the dimension "Responsiveness", with an average of 4.10.

The dimensions with highest averages are "Responsiveness" and "Tangibles", with averages of 3.59 and 3.37, respectively. These dimensions show that the willingness to help and provide immediate service and the UR's physical facilities contribute to a perception of good quality.

The "Reliability", "Empathy" and "Assurance" dimensions have the lowest averages, with 2.59, 2.89 and 3.12, respectively. "Reliability" shows a lower average, which means that the restaurant's ability to deliver the promised service with precision is lacking.

In regards to the second lowest average, that concerns the individualized attention, approach and communication that employees give to the consumer, it can be pointed out a lack of preparation of employees who are in direct contact with UR customers. According to Teboul (1999), interaction with employees is one of the factors that contributes to the perception of service quality.

The third lowest average (3.12) is of the "Assurance" dimension and refers to the employees' knowledge and courtesy and their ability to convey confidence and security. This leads us to interpret that, in the customers' perception, employees have low knowledge of the service processes and there is a need for requalification on that matter. 


\section{Analysis of Perception of Quality by Item}

Table 6 shows the percentage results of each characteristic evaluated under the perception of users of the services provided by the restaurant. Below are exposed the 22 items that make up the groups of the five dimensions of service quality.

Table 6 - Results of quality items

\begin{tabular}{|c|c|c|c|c|c|}
\hline Tangibles & $\begin{array}{l}\text { DT } \\
(\%)\end{array}$ & $\begin{array}{l}D \\
(\%)\end{array}$ & $\begin{array}{l}S / R \\
(\%)\end{array}$ & $\begin{array}{l}\mathrm{C} \\
(\%)\end{array}$ & $\begin{array}{l}\mathrm{CT} \\
(\%)\end{array}$ \\
\hline $\begin{array}{l}\text { 1. The equipment used by the UR is maintained and } \\
\text { modern. }\end{array}$ & 8,1 & 20,0 & 19,0 & 44,5 & 8,1 \\
\hline $\begin{array}{l}\text { 2. The UR facilities (tables, decoration, facade) and the } \\
\text { setting (cleanliness of the environment, air } \\
\text { conditioning) are visually attractive and pleasant. }\end{array}$ & 10,9 & 30,0 & 11,8 & 32,7 & 14,5 \\
\hline 3. UR employees are clean and professional looking. & 2,7 & 8,1 & 18,2 & 48,1 & 22,7 \\
\hline $\begin{array}{l}\text { 4. The appearance of the UR materials associated with } \\
\text { the service (plates, cutlery, buffet food) are arranged in } \\
\text { an easy and hygienic way. }\end{array}$ & 7,2 & 10,9 & 13,6 & 49,1 & 19,1 \\
\hline \multicolumn{6}{|l|}{ Reliability } \\
\hline $\begin{array}{l}\text { 5. When the UR promises customers something, it } \\
\text { delivers in a satisfactory time. }\end{array}$ & 13,6 & 19,1 & 46,3 & 14,5 & 6,3 \\
\hline $\begin{array}{l}\text { 6. The UR provides sufficient and pleasant food service } \\
\text { throughout the opening hours. }\end{array}$ & 23,6 & 35,4 & 13,6 & 22,7 & 4,5 \\
\hline 7. The food provided by the UR is reliable. & 9,0 & 28,2 & 37,2 & 24,5 & 0,9 \\
\hline 8. The UR does not make any type of error in its services. & 28,2 & 47,2 & 20,0 & 4,5 & 0,0 \\
\hline $\begin{array}{l}\text { 9. When errors occur, the UR records them and its } \\
\text { employees show interest on resolving them. }\end{array}$ & 7,2 & 20,0 & 49,0 & 19,1 & 4,5 \\
\hline \multicolumn{6}{|l|}{ Responsiveness } \\
\hline 10. The UR keeps customers informed about the menu & 2,7 & 8,1 & 9,1 & 36,3 & 43,6 \\
\hline
\end{tabular}




\begin{tabular}{|l|l|l|l|l|l|}
\hline offered on each day. & & & & & \\
\hline 11. UR employees are quick on getting the job done. & 0,9 & 18,1 & 13,6 & 50,0 & 17,2 \\
\hline $\begin{array}{l}\text { 12. UR employees are always willing to help customers. } \\
\text { 13. UR employees always respond to customer } \\
\text { requests. }\end{array}$ & 3,6 & 13,6 & 27,2 & 43,6 & 11,8 \\
\hline $\begin{array}{l}\text { Assurance } \\
\text { 14. UR employees inspire confidence from their } \\
\text { customers. }\end{array}$ & 4,5 & 20,9 & 34,5 & 35,4 & 4,5 \\
\hline $\begin{array}{l}\text { 15. UR offers security to its customers. } \\
\text { 16. UR employees are polite. }\end{array}$ & 4,5 & 25,4 & 27,2 & 35,4 & 7,2 \\
\hline $\begin{array}{l}\text { 17. UR employees are knowledgeable about their } \\
\text { products. }\end{array}$ & 3,6 & 19,0 & 53,6 & 18,2 & 5,4 \\
\hline $\begin{array}{l}\text { Empathy } \\
\text { 21. The UR is concerned about what customers like to }\end{array}$ & 18,1 & 30,0 & 29,1 & 20,0 & 2,7 \\
\hline $\begin{array}{l}\text { 18. UR employees are attentive. } \\
\text { 19. UR employees know your needs. }\end{array}$ & 4,5 & 19,1 & 24,5 & 47,2 & 4,5 \\
\hline $\begin{array}{l}\text { 22. The UR is concerned about queve agility. } \\
\text { Source: Prepared by the authors } 2019.1\end{array}$ & 33,6 & 18,1 & 34,5 & 5,4 \\
\hline
\end{tabular}

Source: prepared by the authors, 2019.

Analyzing the Tangibles dimension items, it is observed that, in general, most of the respondents Agree or Totally Agree with the statements, that is, they judge the physical facilities of the UFBA UR as of good or excellent quality. According to Gianesi and Corrêa (1994), this criterion is very important for most services due to the difficulty that customers have to evaluate the service before purchase, that is, physical appearance is the first aspect that 
will determine the good or bad quality of service when the customer has a first contact with the company and has not yet experienced the service as a whole.

We can observe that the equipment conservation (item 1), the appearance of the employees (item 3) and the way in which the materials of use, such as cutlery and buffet dishes, are arranged (item 4), are well evaluated by the respondents. However, aspects of the facilities and setting, such as the decoration, cleaning and air conditioning of the environment (item 2), are not so well evaluated, presenting a percentage of $40.9 \%$ of Disagreement or Total Disagreement, which indicates that the restaurant needs to do more, especially in cleaning and air conditioning.

When analyzing the Reliability dimension of the restaurant, it is noticed that, in general, this category is not well evaluated by users. Adding the results, $75 \%$ of the respondents disagree or totally disagree with the statement that the UR does not make any type of error in its services (item 8) and the quantity and quality of food is not pleasant during the entire opening hours (Item 6), according to $59 \%$ of respondents.

That said, we can interpret that the UR is not transmitting confidence to its customers. According to Parasuraman, Zeithaml and Berry (1988), the Reliability dimension is the most important to meet expectations and therefore it must be a priority. The Responsiveness dimension is the best evaluated by the survey respondents. According to Gianesi and Corrêa (1194), the treatment that customers receive during contact with the service will show how much the company is interested on them.

Item 10 was the best rated, with $43.6 \%$ of Total Agreement and $36.3 \%$ of Agreement, which means that the UFBA UR is concerned with keeping customers informed about the menu of the day. Item 11 is the second best rated in this group, with $50 \%$ of respondents agreeing that UR employees get 
services done quickly. However, item 12 - "willingness of employees to help customers" - was not so well evaluated by $24.5 \%$ of the sample.

The Assurance dimension is the third best evaluated in this research, that is, the UR's ability to transmit confidence to the costumer obtained a reasonable quality assessment.

Analyzing the results by item, the UR employees politeness (item 16) is well rated by $48 \%$ of the sample, $39 \%$ of Agreement and $9 \%$ of Total Agreement. $53 \%$ of respondents are neutral, that is, neither agree nor disagree about the knowledge that employees have of the products (item 17), which indicates that this item is more difficult to be evaluated by users. Regarding the confidence inspired by employees (item 14) and the feeling of security in the transactions with the UR (item 15), there is a similarity in the results, with $35.4 \%$ of Agreement for item 14 and item 15. These items also show a higher level of disagreement, with $25.4 \%$ for item 15 and $20.9 \%$ for item 14 .

The Empathy dimension is the second worst assessed. Item 22, corresponding to the agility of the queves, is the one that obtained the worst level of quality, with $40 \%$ of Total Disagreement and $35.4 \%$ of Disagreement. Item 21, related to the UR's concern about what customers like to eat, is also poorly rated, with 18\% Total Disagreement and 30\% Disagreement.

These two results lead us to affirm that the UFBA UR needs to better understand the users' needs in order to better serve them. It is important that the management of the university restaurant at UFBA seeks to better understand consumer behavior, tastes and preferences. According to Parasuraman, Zeithaml and Berry (1988), service companies must continually seek to understand what their customers expect from the service.

However, item 20, corresponding to the opening hours, is one of those that have the best evaluation, with $53.6 \%$ of Agreement and $16.3 \%$ of Total Agreement. The attention that UR employees pay to customers (item 18) got a good rating, with $47.2 \%$ agreement. After analyzing and interpreting the 
data collected in the survey, the final considerations will be made in the next section.

\section{FINAL CONSIDERATIONS}

The present work aims to evaluate the quality of services provided by the university restaurant of the Federal University of Bahia, located on the Ondina campus, in the perception of its users. To this end, a quantitative study was carried out with the application of a survey, using the SERVPERF instrument, by Cronin and Taylor (1992), with the necessary adaptations for the UFBA UR context. This is because this instrument allows the researcher to assess the quality of services in a more efficient and practical way than the SERVQUAL scale, developed by Parasuraman, Zeithaml and Berry (1988).

After the analysis, it is noticed that, in general, the restaurant presents a good level of quality, according to the evaluation of its customers. Higher levels of quality are achieved in the dimensions of Responsiveness, Tangibles and Assurance, with averages of $3.59,3.37$ and 3.12, respectively.

However, it is found that aspects such as Reliability and Empathy deserve special attention since they have the lowest averages, with 2.59 and 2.89 respectively. Reliability shows a lower average, which means that the restaurant's ability to deliver the promised service with accuracy is lacking. According to Parasuraman, Zeithaml and Berry (1988), the Reliability dimension is the most important to meet customer expectations and must be a priority. Therefore, improving employee training is a measure that will directly impact the quality of the offered services.

Regarding Empathy, it is observed that waiting time in the queve is the main difficulty of the UR, that is, a large portion of respondents are not satisfied with the time they need to wait in line to eat. According to Gianesi and Corrêa (1994), the time that a customer has to wait in all phases of the service greatly influences their perception of quality. So it is of fundamental 
importance that the UFBA UR management checks the matters that are influencing the waiting time in the queve, since, as it is a university, such problem can negatively impact the time that students have to carry out their various academic activities.

Another poorly evaluated point in the Empathy dimension refers to the UR's concern with what customers like to eat, which leads us to affirm that the restaurant needs to better understand its customers' wants and needs in order to better serve them. It is advisable that service companies continually seek to understand what their customers expect from the service, according to Parasuraman, Zeithaml and Berry (1988), which can be done through Marketing research.

One of the study's limitations is the number of respondents in the sample, which does not allow generalizations. As a suggestion for future studies, it is possible to develop qualitative works with students, using the focus group technique, as well as adding new variables to the survey to gain more insights. Studies on affirmative policies for maintaining students with socioeconomic vulnerability in universities and on the organizational perspective of the UR management processes are also suggested.

\section{BIBLIOGRAPHIC REFERENCES}

Coutinho, M. J. V. (2000). Administração pública voltada para o cidadão: quadro teórico conceitual. Revista do Serviço Público, 51 (3), 3-130.

Cronin JR, J. J.; \& Taylor, S. A. (1992). Measuring service quality: a reexamination and extension. Journal of marketing, 56(3), 55-68.

Fernandes, J. C. S. (2016). Análise da qualidade do serviço do restaurante universitário do campus do pici da Universidade do Ceará realizadas pelos alunos do centro de tecnologia. Monografia. Universidade Federal do Ceará, Fortaleza. 
Gianesi, I. G. N.; \& Corrêa, H. L. (1996). Administração estratégica de serviços: operações para a satisfação do cliente. São Paulo: Atlas.

Lovelock, C.; Wirtz, J.; Hemzo, M. A. (2011). Marketing de Serviços: pessoas tecnologia e estratégia. $7^{a}$ Edição. São Paulo: Pearson Prentice Hall.

Malhotra, N. K. (2011). Pesquisa de marketing: foco na decisão. São Paulo: Pearson.

Marconi, M. A.; \& Lakatos, E. M. (2003). Fundamentos de Metodologia Científica. São Paulo: Atlas.

Oliveira, N. M. C. (2013). Simulação a eventos discretos para redução do tempo de espera em um restaurante. Dissertação de mestrado. Universidade Federal de Itajubá. Itajubá: MG.

Parasuraman, A.; Zeithaml, V. A.; \& Berry, L. L. (1985). A conceptual model of service quality and its implications for future research. Journal of marketing, 49(4), 41-50.

Parasuraman, A.; Zeithaml, V. A.; \& Berry, L. L. (1988). Servqual: A multiple-item scale for measuring consumer perceptions of service quality. Journal of retailing, 64(1).

Pena, M. M. et al. (2013). O emprego do modelo de qualidade de Parasuraman, Zeithaml e Berry em serviços de saúde. Rev. Esc. Enferm USP, 47 (5): $1235-40$.

Rossi, C. A. V.; \& Slongo, L. A. (1998). Pesquisa de satisfação de clientes: o Estado-da-Arte e proposição de um método brasileiro. RAC, 2(1), 101-125.

Santos, V. M. (2016). Qualidade percebida e satisfação do consumidor quanto à prestação de serviços do restaurante universitário da UFPE. Dissertação - Universidade Federal de Pernambuco.

Sguissardi, V. (2005) Universidade Pública Estatal: entre o público e o privado/mercantil. Educação \& Sociedade, 26, 191-222. 
Silva, W. F. (2017). Requisitos para implantação de um restaurante universitário de qualidade no CEFET/RJ. Dissertação (Mestrado) Universidade Federal Fluminense, Niterói.

Souza, C. (2006). Políticas públicas: uma revisão da literatura. Sociologias, $8(16), 20-45$.

Teboul, J. (1999). A era dos serviços: uma nova abordagem de gerenciamento. Rio de Janeiro: Qualitymark.

Trevisan, R. et al. (2009). Satisfação dos usuários de serviços públicos municipais: construção e validação de um instrumento. Revista de Ciências administrativas. 15(1), 262-281.

Vidrik, K. (2006). N. Indicadores de qualidade do restaurante universitário da Universidade do sagrado Coração, Bauru, SP: um estudo de caso. Dissertação (Mestrado), Universidade Anhembi Morumbi, São Paulo. 